\title{
HYPOTHERMIA FOR ADULT CARDIOVASCULAR SURGERY: A TECHNIQUE OF ANAESTHESIA
}

\section{H. BARfue FatrLeY, M B , B.S., F.F.A.R.C.S ${ }^{*}$}

At THE TORONTO GENERAL HOSPITAL various methods of anaesthesia have been used in association with hypothermia for adult cardiovascular surgery. However, as one became increasingly aware of the dangers of metabolic acidosis (1) and noted the clinical picture of acute rewarming acidosis (2), it was necessary to introduce a technıque, designed to mantain the acid-base balance within normal limits. The problems of this acid-base relationship are discussed, in detail, elsewhere (2)-the sole purpose of this communication being to outline one technique which has proved most satisfactory in a wide variety of adult cardiovascular cases, with and without circulatory occlusion.

This technique is intended to achieve the following.

1. Maintenance of some degree of ventlatory constancy, in such a way as to hold the blood $\mathrm{pH}$ between 7.35 and 7.45 units. The coincident presence of metabolic acidosıs and respiratory alkalosis would give such $\mathrm{pH}$ values, but the resulting reduction in avalable base is to be avoided Consequently, an attempt is made to prevent the production of acid metabolites by

2. Avoiding shivering.

3. Maintaining some degree of peripheral vasodilatation

4. Careful replacement of blood loss.

\section{Premedication}

\section{TECHNIQUE}

On the evenıng before operation, promethazme $100 \mathrm{mgm}$. 1s given, orally

On the day of operation, chlorpromazine $50 \mathrm{mgm}$. and promethazine $50 \mathrm{mgm}$ are given intramuscularly, one hour before operation This is reduced by one-half in diminutive patients.

\section{Induction}

The patient is brought to the operating room, drowsy, where a sample of venous blood is taken to establish the preoperative $\mathrm{pH}$ level. Measurements are made, in the operating room suite, with a Beckman glass electrode $\mathrm{pH}$ meter and results are available within five minutes of sampling.

An intravenous infusion of $250 \mathrm{ml} 5$ per cent dextrose in water is started. This contains $50 \mathrm{mgm}$. each of chlorpromazine, promethazıne, and meperidine and is

-Department of Anaesthesia, Unversity of Toronto, and Toronto General Hospital.

96,

Can Anaes Soc J, vol 4, no 2, April, 1957 
run in over a twenty- to thirty-minute period. It is stopped earlier if the eyelash reflex is abolished. For nearly every patient, a face piece may be used to give nitrous-oxide : oxygen 4L/2L (for two or three minutes, to confirm comp_ete anaesthesia); but, for the occasional resistant patient, minimal thiopentone sodium will be necessary. Intubation, with a large cuffed endotracheal tube, is carried out under suxamethonium 50 mgm.

\section{Maintenance}

The endotracheal tube is attached to a positive-negative phase (Jefferson) ventilator, through a to-and-fro system. Nitrous-oxide : oxygen is given in a flow varying from $3 \mathrm{~L} / 3 \mathrm{~L}$ per min. to $3 \mathrm{~L} / 1 \mathrm{~L}$ per min Soda lime may or may not be used, as will be discussed later.

On the resumption of spontaneous respiration, d-tubocurarine $18 \mathrm{mgm}$. is given.

The patrent is placed on the pre-cooled bottom Thermorite blanket (3), E.C.G. leads are attached and rectal and oesophageal thermocouple leads inserted.

An intravenous infusion of 5 per cent dextrose in water is started, in one arm, through a no. 15 S.W.G. needle and a no. 17 S.W.G. needle is inserted into the external jugular vem and connected to a small bottle of 5 per cent dextrose in water, through a three-way stopcock. Th1s is of value $(a)$ for inserting drugs intermittently and $(b)$ for sampling blood for $\mathrm{pH}$ values.

The practice has been to obtam arterial bloor samples from the radial artery, using a Cournand needle mserted blindly. In right-handed people, this is inserted in the left radial artery, provided there is a palpable ulnar pulse The only trouble encountered has been that of keeping the needle in the artery-especially in the recovery period. Because of this, the current preference is for a modification of the Seldınger technique (11) of sampling from the brachial artery. It is, of course, simpler to perform percutaneous vascular cannulations before cooling starts

The patient is covered with crushed ice (the wetting effect makng this supenor to ice bags) and the top Thermorite blanket put in place A minimal antiTrendelenburg tht is used, to allow meltung ice to drop into a container at the lower end of the table. The blankets are covered with a white sheet to prevent temperature changes by radiation

Fluctuations in room temperature influence the cooling rate markedly. For this reason, thermostatically controlled aur conditioning is of value.

The top blanket is removed when the patient's temperature is a few degrees above the desired optumum temperature (for example, at $33{ }^{\circ} \mathrm{C}$ for $29^{\circ} \mathrm{C}$.) and the operation is commenced. By the tme the heart is exposed, a further temperature drop, or drift, will have occurred. It is noted that the nesophageal temperature tends to change before the rectal reading (5), although this may differ in patients with septal defects Thus, if the oesophageal temperature is lower, 
further drift will probably occur. The difference between the oesophageal and rectal temperatures, speed of coolng, and size of patient are factors which are considered to be indications of the amount of drifi to be expected.

If shivering occurs in the first thirty to forty-five minutes on the blanket (easily noted on the E CG oscilloscope), more d-tubocurarine is given. After that, shivering is taken as an indication for further chlorpromazine. Large doses of chlorpromazine are thus avouded, at the unstable time of induction. Difficulty in inflation or attempted respiration is taken as an indication for further d-tubocurarine, although the stımulus to respiration of arrest of the cerebral circulation should be remembered if sudden gasping respiratory eforts occur when a patient is in the higher temperature ranges.

Prior to circulatory occlusion, 100 per cent oxygen is given for a few minutes During occlusion, gross pupillary dilatation occurs and no further nitrous-oxide is given until this is reversed and the patient shows some reflex movement-a sign of viability of the CNS This stage is usually reached within one to fifteen minutes of restoring normal circulation, the pupils constrictung first. Commonly, the next change noted is the return of spontaneous respiratory movements, which may be abolsshed with 50 per cent nitrous-oxide, in many instances!

Virtue describes pupillary dilatation throughout hypothermia (6), but this has not been observed in using this technique, the lowest temperatures (rectal) reached being above $28^{\circ} \mathrm{C}$

After the period of occlusion, the flud in the bottom blanket is rewarmed by turning on the pump, the fluid in the Thermonte unit having been rewarming during the first part of the operation.

\section{Ventilation}

The tendency to produce respiratory alkalosis with controlled respiration (7) is avoided by adjusting (1) the presence or absence of soda lime in the crrcuit and (ii) the total flow of gases It is found that, in a young adult with healthy lungs, no soda lime will be necessary at all and the flow may have to be reduced to $4 \mathrm{~L}$ per min. In the more elderly patient, soda lime may be necessary to maintain a normal blood $\mathrm{pH}$ level While clinical assessment is of considerable value in judging the ventilatory curcumstances which will be required at the outset, adjustment is made, durng the operation, according to the blood $\mathrm{pH}$ values obtained. The respuratory rate is kept constant

With regard to the Jefferson ventilator, it is felt that it is preferable to use this apparatus with a to-and-fro system, thus reducing the elasticity to about onethird of that in a crrcle-type cucuit As a result, hypoventilation is less likely to occur.

At the end of operation, spontaneous respiration is permitted as soon as the chest is closed, the patient then being better equipped to control his own acidbase balance An antı-cholinesterase is given routnely, since sub-clinical residual curarisation may prevent the necessary hyperventilatory response to the produc- 
tion of acid metabolites (2). In this connection, it is noted that the increased "vagotonia" of hypothermı potentrates the parasympathominetic effects of the ant-cholinesterases. Consequently, greater doses of atropine than usual should be given Severe bradycardıa has been seen even after giving edrephonium

\section{Heart Action}

Fibrillation Aurcular fibrllation has been observed in some cases. Should this produce an immediate rise in heart rate, the resulting cardiac inefficiency may cause a fall in blood pressure. The sequence, normal blood pressure-auricular fibrillation with tachycardıa--hypotension-ventricular fibrillation, has been observed and it is recommended that, if auricular fibrillation occurs with an associated tachycardia and hypotension, this be considered an emergency situation Ouabaine 0 25-0.5 mgm is given intravenously. On occasions when this has been done, ventricular fibrillation has not followed the auricular arrhythmiawhich may even revert to sinus rhythm The advantages of this drug's quick, shoit-acting effect offset the possible disadvantage of the action of digitalis glycosides on the excitability of the myocardium. This opinion is based on the belief that myocardial ischaemia is the chief cause of ventricular fibrillation and that other factors are of secondary importance. Acetyl strophanthidine has not been used in these crrcumstances but may prove even more applicable.

In this centre, blood pH during cooling and operation has usually been maintained at normal levels, or above, and ventricular fibrillation has only occurred at such levels Thus, having no clinical experience of ventricular fibrillation in association with acidosis (except as a terminal event in the acute acidotic syndrome of rewarming), no opınion can be given about the need for hyperventlation as an antı-fibrillatory measure The current view is merely that adequate ventilation is all that is required.

Bradycardia Lowering the body temperature results, classically, in a fall in heart rate This is seen in clinical hypothermia and is disregarded unless there is an associated hypotension. Should the two occur together, atropine $02 \mathrm{mgm}$ is given intravenously and is very frequently effective.

It is not accepted that hypotension is a necessary accompanment of clinical hypothermia On the contrary, it is felt that it is to be avorded as one of the main causes of complications arising during the procedure.

\section{Rewarming Period}

The patient is dried and placed in bed with hot-water bottles (maximum temperature $100^{\circ} \mathrm{F}$ ) The endotracheal tube is left in situ untıl the patient begins straining or coughing on it Oxygen is given. either through this or, after its removal, by nasal catheter Shivering is an immedrate and urgent indication for 
chlorpromazine ( $25 \mathrm{mgm}$. I.V.), which will probably have to be repeated. Occasionally, a patient will be awake and shiverng and complaining of pain. Shivering and complaint of pain is an indication for meperidine ( $25 \mathrm{mgm}$. I.V.), not further chlorpromazine, which will only result in piolonged depression, as the complaint of pain will contnue and the meperndme will be required in addition. These patients all having had chlorpromazine before, it seems that meperidine alone is sometimes effective in abolishing shivering comcidentally to its use as an analgesic

The $\mathrm{pH}$ is determmed at intervals and an intial fall $\mathrm{in} \mathrm{pH}$ is the constant pattern. This does not usually go below 725 and, once tt has started to rise again and the patient is awake and breathing well, he may be handed over to a special postoperative nurse with instructions to give chlorpiomazine ( $25 \mathrm{mgm}$.) intravenously, and to call someone immediately should shivering occur. It is not desirable to return patients to the ward under $34^{\circ}-35^{\circ} \mathrm{C}$. and no special nurse has yet had to give chlorpromazine

Should the acute acidotic syndrome develop, the ummediate treatment is (1) a large dose of muscle relaxant-it is possible that succinylcholine is inadvisable in the presence of the vagotonia of hypothermia and decamethonium (5 mgm.) is preferred, (11) vigorous hyperventilation Intravenous bicarbonate may be necessary (2)

\section{Discussion}

Dundee has demonstrated the value of chlorpromazme in aiding cooling (8) and Gray has described its use in nine cardiovascular cases (9). Code Smith finds the "lytic cocktall" safe in paediatric cardıovascular surgery (10).

The technique-used by Vandewater for neurosurgery (11) provides $\mathrm{pH}$ levels within normal limits throughout cooling, operation, and rewarming period, using spontaneous respiration (12) with a chlorpromazine mixture

The method outlmed above has been used for several patients in whom a fall in peripheral resistance might be considered serious No gross hypotension or tachycardia has been encountered. A stable heart rate and blood pressure throughout the procedure has been the rule The only exception has been the period of occlusion, after which a quick return of blood pressure has been observed.

The main objection to the technique has been the added difficulty of the inefficacy of adrenaline as a cardiac resuscitatng agent. However, calcium chloride has been used as a means of restoring myocardial tone and, with the present confusion as to the relative merits of these two drugs, the serrousness of this disadvantage cannot be assessed

Using d-tubocurarine and chlorpiomazme durmg the operation, the level of central depression is not so great as to make it impossible to assess the reflex response, etc., should a cardiac emergency anse durnng the operation. The avoidance of thiopentone, when possible, and the low dosage of meperidine may account for this somewhat unexpected asset 
In the attempt to avoid respiratory alkalosis, it is of importance to note that hyperventilation with, say, 5 per cent carbon dioxide would prevent a fall in alveolar $\mathrm{CO}_{2}$ much below the normal 5.6 per cent and maintain the arterial $\mathrm{CO}_{2}$ tension at a constant level. However, if a patient's ventilating mechanism is pathological (for example, emphysematous), this could result in respiratory acidosis. Thus, the routine use of 5 per cent $\mathrm{CO}_{2}$ with hyperventilation, as a means of avoiding respiratory alkalosis, is, possibly, ill advised in adults. Hence the use of the technique of ventilation described. Tidal volumes based on the Radford nomogram (13), which is dependent upon body weight and respiratory rate, cannot be utilized since this does not take into account the possibility of pathological pulmonary variations Experience with this method of controlling ventilation has shown that great variations may be necessary from patient to patient.

It will be appreciated that, durıng hypothermia, a constantly varying situation exists with regard to acid-base balance. Of necessity, one is destroying the patient's means of moment-to-moment adjustment by controlling the respiration. Herein lies the essental diflerence between the circumstances attending anaesthesia for neurosurgery and those attending anaesthesia for cardiovascular surgery. Whereas the neurosurgical patient may control his own balance, the patient with controlled respiration requires frequent assessment as to how this balance is proceeding. Intermittent blood $\mathrm{pH}$ readings are the best single indication but do not distinguish metabolic from respiratory factors. This may be done by measurnng alveolar $\mathrm{CO}_{2}$ levels in addition, or, in view of the frequent presence of some degree of error (for: example, difficult sampling or right to left shunt), the more time-consuming and, therefore, less avalable total blood $\mathrm{CO}_{2}$ or bicarbonate levels.

Abdominal aortic surgery For patients requirnng abdominal aortic occlusion, proximal to the renal vessels a similar technique is used. However, greater doses of chlorpromazine, promethazine, and meperıdıne are necessary. On removing the abdominal aortic clamps, a further temperature drop is to be expected, presumably owing to the return of cold blood from the relatively static circulation in the legs.

In conclusion, it is pointed out that, although clinical hypothermia has been in use for some years, the continued collection of experimental data renders the clinical techniques subject to frequent readjustment

\section{SUMMARY}

A detailed description and discussion is given of the anaesthetic and hypothermia technique currently in use at the Toronto General Hospital for cardiovascular surgery. It is amed at avoiding acid-base imbalance and the resulting acute acidotic syndrome of rewarming. The monitoring of the acid-base balance is briefly discussed. 


\section{ACKNOWLEDGMENTS}

The author would like to express his indebtedness to Dr. W. G. Bigelow for his constant interest and encour agement, to Dr. W. G. Waddell, Surgical Research Fellow, for his invaluable assistance and advice, and to his colleagues on the anaesthetic staff of the Toronto General Hospital, tor therr coverage of other commitments while this work has progressed

\section{RÉSUMÉ}

Cet article donne une descinption détallée de la technıque d'anesthésie avec hypothermie, employée couramment au cours de la chırurgie cardıovasculaire à l'hôpital Toronto General

Dans la littérature, pour facıliter le 1 efroıdıssement, on a conselllé des mélanges contenant de la chlorpromazine et on a fatt une mise en garde contre les dangers de l'acidose métabolique

Avec la technique que nous piéconisons actuellement, nous employons de la chlorpromazine, de la promethazine et de la mépéridıne dans le but de maintenir dans le sang une concentration normale et uniforme en ions Hydrogène et d'éviter aussi, au moment du réchauffement, le syndıome de l'acidose aigue

Le maintien de l'anesthésie se fait par le protoxidle d'azote et l'oxygène et, à l'aide d'un ventilateur automatıque et de l'usage intermittent de D-tubocurarine, nous contrôlons les échanges respiratorres Nous ajustons ces échanges de façon à éviter l'alcalose respiratorre durant le 1 efroidıssement aussi bien que durant l'opération

Nous donnons, en détall, les avantages et les désavantages de cette technique Le princıpal inconvénient réside dans l'uction anti-adrénalinique de la chlorpromazine Cela dimınue la valeur de l'adrénalıne dans l'occurrence d'insuffisance cardiaque

\section{REFERENCES}

1 Brewin, E G, Nashat, F S \& NeIL E Acid-Base Equilibrium in Hypothermia Brit J. Anaesth, 281 (1956)

2 Fatrley, H B, Waddell, W G \& Bigelow, W G Hypothermia for Cardiovascular Surgery Acidosis in the Rewarming Period For submission to Brit J Anaesth (1957)

3 Bigelow, W G, Mustard, W T \& Evans, J G Some Physiological Concepts of Hypothermia and their Application to Cardiac Surgery J Thoracic Surg, 28463 (1954)

4 Seldinger, S I Catheter Replacement of the Needle in Percutaneous Arteriography Acta Radiol., 39368 (1953)

5 Gerbrandy, J, Sneld, E S \& Cranston, W I Oral, Rectal and Oesophageal Temperatures in relation to Central Temperature Control in Man Clin. Sci., 13615 (1954)

6 Virtue, R W Hypothermic Anaesthesia Springfield, Jll Charles C Thomas (1955)

7 Scurr, C F Pulmonary Ventılation and Carbon Dionde Levels during Anaesthesia Brit. J Anaesth, 28422 (1956) 
8 Dundee, J W., Mesham, P. R. \& Scott, W E B Chlorpromazine and the Production of Hypotherma. Anaesthesia, 9: 296 (1954)

9 Gray, T. C. Discussion on Induced Hypothermia Proc. Roy Soc. Med, 48. 1083 (1955)

10 SMITH, CoDe Anaesthesia for the Surgical Correction of Congenital Heart Disease Canad. Anaesth Soc. J., 2. 347 (1955).

11 Vandewater, S L, Botterixt, E. H. \& Lougheed, W. M. A Method of Anaesthesia and Hypothermia in Cerebral Vascular Surgery Canad Anaesth Soc J, $2 \quad 319$ (1955).

12 VANDEWater, S L Personal communication.

13 Radfond, E P, Jr J Appl Physiol, 7. 451 (1955). 